\title{
CAN RAINMAKERS JUSTIFY THEIR PAY? THE ROLE OF INVESTMENT BANKS IN REIT M\&As
}

\author{
Weiwei ZHANG ${ }^{1}$, Tiezhu SUN ${ }^{2,}$, Patrick Han Lin $\mathrm{GOH}^{3}$, Zilong WANG ${ }^{3}$, Nick MANSLEY ${ }^{3}$ \\ ${ }^{1}$ Changchun University of Science and Technology, Changchun, China \\ ${ }^{2}$ Changchun Guanghua University, Changchun, China \\ ${ }^{3}$ Department of Land Economy, University of Cambridge, Cambridge, UK
}

Received 01 September 2020; accepted 11 February 2021

\begin{abstract}
This study explicitly rejects the prima facie proposition that the top-tier investment banks are capable of delivering supernormal value creation to the shareholders of a REIT acquirer in a corporate acquisition. Using the event study method, we find that REIT acquirers advised by market-leading investment banks suffer an average cumulative abnormal return of $-4.41 \%$ following the M\&A announcement, whereas REIT acquirers advised by non-top-tier investment banks only suffer an average cumulative abnormal return of $-1.49 \%$. The evidence shows that the contemporary practice of employing investment banks based on the prestige of the advisory firms could potentially result in value-destroying M\&As for the REIT acquirers.
\end{abstract}

Keywords: Real Estate Investment Trust (REIT), mergers and acquisitions, financial advisor, investment bank, event study.

\section{Introduction}

Real Estate Investment Trusts (REIT) have increased in size dramatically since their establishment in 1960. US REITs had a market capitalisation of only \$32bn in 1993 but this has grown to $\$ 1,328$ bn by 2019 , meanwhile the number of REITs is little changed from the mid 1990s (219 in 2019 compared to 226 in 1994). In the pursuit of external growth, efficiency gains and strategic expansion, numerous REITs have utilised mergers and acquisitions (M\&As). Total M\&A deals in the REIT industry recovered after the GFC and, as illustrated in Figure 1, reached a new record deal value of over \$71 billion in 2018 .

Given the REIT sector and the companies within it have grown so rapidly the role of financial advisors in supporting that growth and in creating value for their REIT clients is particularly of interest. A financial advisor should ensuring that the advisory services provided are in favour of its client's interest. An investment bank's reputational risk is intensified in a public transaction (Rhee \& Valdez, 2009). On the other hand, the complexity of acquiring a private target relies more on the bargaining power and deal sourcing capabilities of their advisers, implying a need for significant effort from the financial advisors for private transactions.
In firms with strong corporate governance in place, the strategic decision to employ an M\&A financial advisor should be driven by the intention to maximise shareholder wealth (Shleifer \& Vishny, 1997). A financial advisor representing the client in a merger transaction should act in the best interests of the firm's shareholders by negotiating better corporate acquisition terms and a lower premium while the financial advisor for the target firm should seek to increase the deal premium. In an efficient market, the extent to which a corporate takeover benefits the shareholder of the event firm will be instantly reflected in its share price during the merger announcement period. If top-tier investment banks are able to provide better M\&A advisory services for their clients, this should be reflected in higher abnormal returns of acquirers who are advised by leading financial advisors, which, in turn, will help to justify the investment bank's higher advisory fees (Rau, 2000; Hunter \& Jagtiani, 2003). Hence, the question which this paper addresses - do top-tier investment banks create value for an acquirer firm in an M\&A transaction? There are contradicting results in the corporate finance literature concerning the value-enhancing role of the leading M\&A advisors. As top-tier financial advisors often charge a reputation premium when providing advisory services,

${ }^{*}$ Corresponding author. E-mail: beijixiong2020@126.com

Copyright $\odot 2021$ The Author(s). Published by Vilnius Gediminas Technical University

This is an Open Access article distributed under the terms of the Creative Commons Attribution License (https://creativecommons.org/licenses/by/4.0/), which permits unrestricted use, distribution, and reproduction in any medium, provided the original author and source are credited. 


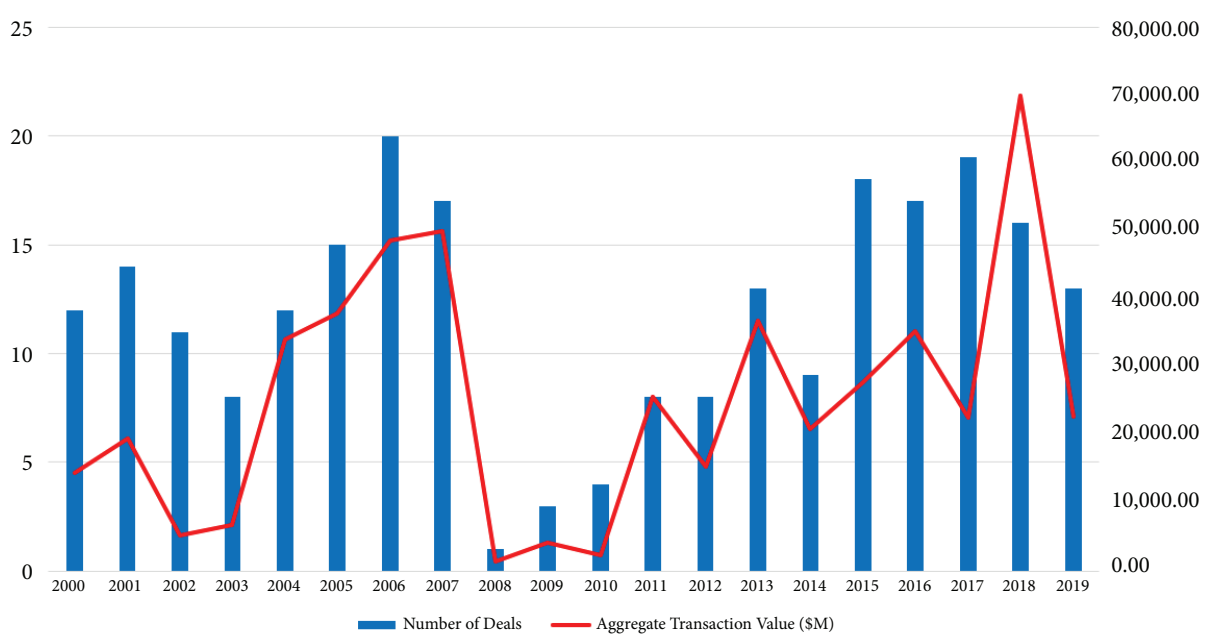

Figure 1. Number of deals and transaction value of U.S. REIT M\&As

this raises a doubt whether it is worthwhile for a bidding firm to employ these advisors.

This paper contributes to the literature by analysing the role of top-tier financial advisors in REIT M\&As. To the best of our knowledge, this is the first empirical study that explicitly addresses the question of the prestige of financial advisors on the wealth implication of the REIT acquirers. Given that the REIT M\&As are dealing with real estate assets, the valuation should be easier and there should be less complexity than in other corporate M\&As. Thus REITs might be an area whether top-tier financial advisors may struggle to really create wealth for their clients. REITs have a particular regulatory and institutional environment and less flexibility on dividend pay-out policy than other corporates. These unique characteristics of REITs, therefore, might result in dissimilar wealth implications to the shareholder of REIT firms in M\&As as postulated by Allen and Sirmans (1987) and Eichholtz and Kok (2008). Due to the $90 \%$ dividend pay-out requirement of U.S. REIT, a considerable proportion of corporate takeovers among REIT entities are financed using a mix of cash and stock while the mergers that are solely financed by internal funds and/or cash are relatively rare. Besides, the unique regulatory requirement of REITs such as the 5-50 rule (the top 5 investors must not account for more than $50 \%$ of the ownership) also greatly reduces the probability of a hostile takeover (Campbell et al., 2001; Bauer et al., 2010). This effectively weakens the mechanism to discipline incumbent managers with opportunistic rentseeking behaviour from engaging in value-destroying corporate agendas (Campbell et al., 2011). Apart from that, Eichholtz and Kok (2008) assert that the diversification potential of REITs is relatively limited due to the requirement to hold no more than $25 \%$ of their total assets outside of the income-generating property assets.

Using the event study method, we find that leading financial advisors, on average, do not enhance the share- holder wealth of its client firms and that the top-tier investment banks fail to deliver extraordinary share price performance vis-à-vis the bidders which retain a nontop-tier financial advisor. The REIT acquirers advised by market-leading investment banks suffer an average cumulative abnormal return of $-4.41 \%$, whereas REIT acquirers advised by non-tip-tier investment banks only suffer an average cumulative abnormal return of $-1.49 \%$. The value-destroying nature of prestigious financial advisors, suggests that the signalling effect of an investment bank's reputation capital does not seem to be momentous among REIT M\&As and that the top-tier investment banks fail to render superior financial advisory services to the REIT acquirers.

\section{Literature review}

\subsection{Motivation of M\&As}

The literature on conventional M\&As suggests that the market for corporate control is driven by the need to pursue economies of scale, market power, synergistic gains as well as cost-based efficiency improvement through horizontal and vertical integrations (Manne, 1965; Asquith et al., 1983; Brealey et al., 2008). Besides, firms often undertake corporate takeovers in the pursuit of enhanced market dominance, competitive advantage, and bargaining power across value chains (Seth, 1990). In accordance with the neoclassical theory of M\&As, corporate acquisitions should only be undertaken by managers if they are perceived as value-enhancing activities which generate positive net present value (NPV) for the combined firm. However, the value-destroying nature of M\&As, evident in both the short and long-run negative excess performance of the acquirers, seems to suggest that public takeovers, to a large extent, fail to create value for the shareholders of bidding firms. 
M\&A activities in the REIT industry are predominantly motivated by external growth, economies of scale, and an enhanced management efficiency (Allen \& Sirmans, 1987; Ambrose et al., 2005; Eichholtz \& Kok, 2008; Glascock et al., 2018). The opportunity to offset the net operating losses (NOL) of target firms against the bidders' tax liabilities also results in REITs with large NOL and deferred tax assets being an attractive potential target for corporate acquisitions ( $\mathrm{Li}$ et al., 2001). Ling and Petrova (2011) discover empirical evidence that the tax advantage of acquiring targets with tax-loss carry-forwards prompt mergers within the REIT sector. Moreover, Eichholtz and Kok's (2008) study finds that under-performing REITs have a higher tendency to become a potential target for corporate acquisitions despite the lack of hostile takeover within the REIT sector. Their findings are consistent with those of Allen and Sirmans (1987) and Womack (2010) on the inefficient management hypothesis as an underlying driver for consolidations within the listed property sector. Thus, the economic gains arising from REIT M\&As are largely attributed to the synergistic and efficiency motivations relative to the search for market bargaining power and monopolistic ability as observed across public mergers among conventional firms.

\subsection{Value creations of M\&As}

The academic literature has arrived at a consensus that merger and acquisitions typically benefit the shareholders of the target firms substantially while a M\&A deal is on average merely a break-even endeavour for the bidders (Andrade et al., 2001; Bradley et al., 1988; Mitchell \& Mulherin, 1996). The gain captured by the target firm implies the anticipated efficiency gains generated by M\&A transactions are disproportionately taken by the target firm. This may be due to an excessive acquisition premium being offered by the bidding firm while some academic studies also point towards the value-reducing theory of M\&A, such as the hubris hypothesis as well as the agency theory of free cash flows associated with managerial entrenchments and empire building (Jensen \& Meckling, 1976; Shleifer \& Vishny, 1989; Morck et al., 1990).

In the context of the public REITs, the empirical findings are generally in line with the earlier studies on the value creation of M\&As among conventional firms whereby a significant value gain is accrued to the target firms whilst the acquirers experience an abnormal return which is either negative or insignificantly different from zero (Allen \& Sirmans, 1987; Elayan \& Young, 1994; Sahin, 2005). Allen and Sirmans (1987) was the first study which analyze the value creation of M\&A in the REIT industry. They found that the acquirer's abnormal return was significantly positive, albeit their sample size was relatively constrained to 38 REIT mergers before the 1990s. However, subsequent studies have consistently shown that the abnormal gain attributable to the bidder is either significantly negative or indistinguishable from zero (Elayan \& Young, 1994; Campbell et al., 2001). It is also worth noting that the excess return accrued to both REIT bidder and targets are found to be lower than those documented for conventional M\&A firms (Elayan \& Young, 1994). Among recent studies on M\&As within the REIT sector, the cumulative abnormal return experienced by a REIT acquirer ranges from a negative and statistically significant return of $-1.60 \%$ to a positive albeit insignificant share price performance of $0.37 \%$ (Eichholtz \& Kok, 2008; Campbell et al., 2011; Womack, 2010). In the long horizon post-merger completion, the underperformance of REIT acquirers is largely in line with the findings of the corporate finance literature (Sahin, 2005; Campbell et al., 2007).

The status of the target firm is a key determinant of the acquirer's return. Corporate finance studies have long concluded that the bidders enjoy a non-negative gain in the takeover of a private firm while public acquisitions are often associated with significant negative abnormal returns. The positive share price reaction towards the acquisition of a private target might be attributed to the liquidity discount argument (Fuller et al., 2002). Consistent with the findings of general corporate finance literature, the acquisition of private targets by public REITs has been found to higher abnormal returns than the takeover of public firms (Campbell et al., 2011). However, the magnitude of abnormal returns is also discovered to be smaller for REIT firms than those documented in the general corporate finance literature.

The means of payment also plays an important role in shaping the shareholder wealth creation of an M\&A transaction. Similar to the findings of Travlos (1987) and Servaes (1991), the difference in the degree of M\&A value creation among REITs is attributable to the payment method during a merger transaction, with cash acquisitions generating the highest abnormal return, followed by the use of mixed financing and lastly stock-financed mergers (Campbell et al., 2011; Ling \& Petrova, 2011). The relatively lower wealth creation attributed to the acquirers using stock payments is associated with the asymmetric information issue and tax considerations. Myers and Majluf (1984) assert that the negative abnormal return in a stock-financed merger stemmed from the negative signalling effect which posits that the bidders' equity is overvalued. As a result of information asymmetry and adverse selection, the bidder is penalised by its shareholder when acquiring a public target. However, the signalling effect is less negative in the takeover of a private target (Eckbo et al., 1990). These might be related to the monitoring effect, as suggested by Chang (1998), in which the formation of block holder brought about stronger internal corporate governance in a public-private corporate takeover. On the other hand, cash-financed acquisitions are often associated with positive and significant abnormal gains to the bidders, regardless of the target status (Travlos, 1987; Chang, 1998).

In the context of REIT M\&As, it is noteworthy that the adverse impact on the use of stock payment is comparatively weaker than those of the conventional firms due 
to the more limited financing methods available to REITs given their regulatory constraints (Campbell et al., 2011), notably the requirement of a high dividend pay-out which results in a low reserve of internal funds and limited cash in the business.

\subsection{Role of investment banks}

The value enhancement role of an investment bank in an M\&A transaction is predominantly derived from two important functions: the better merger hypothesis and the bargaining power hypothesis (Bowers \& Miller, 1990). The better merger hypothesis refers to the ability of an investment bank to source a potential target that is best able to maximise the shareholder wealth of their clients. This function draws upon the resources and skills of an investment bank to act as an efficient intermediary within the financial market (Chemmanur \& Fulghieri, 1994). The bargaining power hypothesis stems from a financial advisor's role in negotiating the transaction price on behalf of the bidding firm. The role of the financial advisor in the offer price negotiation phase is an important determinant of the magnitude of value gains and synergistic surplus attributable to its client firm. Thus, it is reasonable to assume that an investment bank's competitive advantage originates from its expertise and experience in providing superior M\&A advisory services through identifying targets which maximise value creation potential without overpaying for the acquired firm. This is made possible through its economies of scales and scope, analytical capabilities as well as its track record within the industry.

Bowers and Miller (1990) provide empirical evidence supporting the better merger hypothesis. In acquisitions where either the acquirer or target employ first-tier investment banks, the incremental of total shareholder's wealth (acquirer's shareholder's wealth plus target shareholder's wealth) is greater than when neither firm employs a firsttier investment bank. However, as documented in the literature, most of the benefit of M\&As goes to the target's shareholders. Thus, Bowers and Muller (1990) did not find evidence that the acquirer's shareholders benefit from the acquirer employing a first-tier investment bank.

A large proportion of advisory fees are only paid to the financial advisor upon completion of the merger transaction. Thus, the fee structure creates agency conflict between the M\&A financial advisor and the shareholders of the acquirers. This will be exacerbated if the remuneration of the investment banker is influence by market share as well as fee revenue with an additional incentive to complete the deal. Financial advisors are therefore unlikely to be fully aligned with the objective of shareholder value maximisation for the bidding firm when they are rewarded for completing the deal. Rau (2000) shows that the toptier investment banks fail to create value for the acquirer firms as they are inherently motivated by deal completion above the quality of the transaction. He argues that there appear to be two contradicting forces dictating the performance of the financial advisors, namely the superior deal hypothesis and the deal completion hypothesis. The superior deal hypothesis is that an investment bank's prestige is signalled through the quality of its work, and thus a top-tier investment bank should be capable of delivering positive abnormal gains to its client firms. In contrast, the deal completion hypothesis advocates that the contractual fee agreements for the M\&A advisory services prompt the financial advisors towards completing deals irrespective of the value implications for acquiring firms in order to generate fees and increase market share. In a subsequent study, Rau and Rodgers (2002) find that the reputable investment banks are more likely to be hired by acquirers with a larger board size and a lower ownership concentration. However both over short and longer-horizons share price performance of the bidder shows unsatisfactory results when reputable investment banks are employed. They argue that reputable investment banks are hired by managers and directors with poorly-aligned incentives simply to ensure the deal is completed.

The assertion that the top tier investment banks' performance in the M\&A advisory business fails to live up to expectations in terms of the impact on the shareholder's wealth of acquiring firms are supported by other studies. For instance, da Silva Rosa et al. (2004) document the underperformance of top-tier investment banks in Australia M\&A advisory business. Servaes and Zenner (1996) and Ismail (2010) discover evidence that the association between an investment bank's prestige and the acquirer's gain surrounding the merger announcement period is not significant. Hunter and Jagtiani (2003) and Walter et al's (2008) show that the prestigious financial advisors are inherently motivated by the fee structure of the advisory services, thus inevitably giving rise to the conflict of interest between the investment firm and its client in an M\&A transaction. Recent studies by Derrien and Dessaint (2018) have also provided justification for the claim that the investment banks have a high incentive to focus on their position in M\&A league tables.

However, there are studies that show a positive relationship between the reputation of a financial advisor and the shareholder's wealth of acquirers. For instance, Kale et al. (2003) claim that it is important to consider the reputation of the advisor of the target, they show that acquirers with better advisors are associated with wealth gain. Prior studies investigated the importance of investment banks for M\&A outcomes by hypothesizing a measure of advisor quality, such as market share or brand prestige. Such studies will find significant results only if their chosen measures are truly accurate proxies of ability. Instead of using a measure of advisors quality, Bao and Edmans (2011) employ a fixed-effect analysis, and they find that certain banks have the ability to create wealth for their clients. Golubov et al. (2012) show that top-tier advisors can deliver higher acquirer returns than their non-top-tier counterparts in public acquisitions only. The reason is that public acquisitions require more skill and lead to greater reputational exposure to the advisors. Guo et al. (2020) 
argue that the effects of top-tier investment banks depend on the financial condition of the acquirer. Top-tier investment banks improve performance for constrained acquirers rather than neutral, and unconstrained acquirers.

In the REIT sector, the study by Daniels and Phillips (2007) portrays the positive relationship between the financial advisor's prestige and the transaction value of REIT mergers. They find that top-tier investment banks are used for larger transactions. They do not investigate the impact on shareholder's wealth/ share price performances. Thus, the effect of top-tier investment banks on REIT bidder shareholder wealth of s remain unknown and will, therefore, be addressed in this paper.

\section{Data}

The primary data sources are S\&P Global Market Intelligence, Thomson Reuters Eikon and CSRP. The deal screener function in the SNL Market Intelligence is used to obtain a list of U.S. publicly traded equity REITs that have undergone M\&A between 1993 and 2019. Thomson Reuters Eikon is used to complement the SNL platform when data availability issue arises.

Daily returns of REIT acquirers and S\&P500 are obtained from CRSP. Firm accounting data including market capitalisation, the book value of equity, leverage ratio and operating cash flow information of the event firms are retrieved from Compustat. The financial advisor league table for conventional M\&As and the real estate sector M\&As are downloaded from the Thomson Reuters Eikon M\&A database.

The initial sample contains a total of 281 M\&A of all types within the U.S. REIT sector and is subsequently filtered to ensure it is focused on corporate M\&A activity where the acquirer is a U.S. publicly-traded REITs, there is at least one financial advisor for the REIT acquirer and share price information is available on CRSP. Purchases and disposals of minority interests and properties are excluded. The final dataset consists of 100 M\&A deals initiated by the U.S publicly-traded REITs from 1993 to 2019. None of the M\&A deals in the sample is hostile in nature. This is not perceived as a coincidence given the widely documented literature on the lack of hostile M\&As within the REIT sector (Eichholtz \& Kok, 2008; Campbell et al., 2011).

In this paper, the investment bank's reputation is proxied using the rank of total transaction values in M\&A deals. In the spirit of Fang (2005) and Golubov et al. (2012), we use a binary classification in ranking the investment banks whereby the top- 8 firms with the highest total transaction value will be classified as the top-tier financial advisors while the remaining advisory firms fall into the non-top tier category. This is also consistent with the Wall Street's practice of categorising the top 8 investment banks as the "bulge bracket" firms. When corporate takeover among investment banks take place, the new combined entity takes credit for the M\&A deals conducted post-acquisition. For instance, when Merrill Lynch \&
Co was acquired by Bank of America in 2009, all merger deals thereafter are considered as being advised by Bank of America. In the presence of multiple financial advisors for a REIT acquirer, the acquisition is regarded as being consulted by a top-tier investment bank as long as one or more top-tier investment bank is listed as the M\&A financial advisor. These approaches are in line with the practice of academic studies evaluating the reputation effect of financial intermediaries (Bao \& Edmans, 2011; Derrien \& Dessaint, 2018). The ranking used in this study is presented in Table $1^{1}$. The top- 8 financial advisors identified in this paper are Goldman Sachs \& Co, Morgan Stanley, JP Morgan, Bank of America Securities, Citi, Credit Suisse, UBS and Deutsche Bank.

If the top-8 financial advisors are identified as leading financial advisors, the leading financial advisors for M\&A activity among conventional firms are almost the same from that indicated in the study by Golubov et al. (2012), suggesting the consistency of these top-tier investment banks over a long horizon. ${ }^{2}$ The rankings are also largely identical to the bulge bracket investment banks in investment banking industries in other markets across the globe. ${ }^{3}$ Given that the advisory firms specialising in real estate M\&A business might not share the same expertise and reputation as for corporate acquisitions across other industries, we investigated whether there are differences between the league table for conventional M\&As and real estate specific M\&As. The only difference was that, Credit Suisse's position in the top- 8 investment banks category is replaced by Barclays. This difference in top-tier classification is evaluated in the robustness section.

The descriptive statistics for the whole sample and for those advised by the top-tier and non-top tier investment banks are shown in Table 2. The mean (median) of the acquirer REIT's market capitalization is $\$ 4.15$ (\$1.9) billions. REIT acquirers advised by the leading financial advisors are associated with the characteristics of having a greater size and lower book-to-market value. In terms of deal-specific characteristics, it is also obvious that the top-tier investment banks are more likely to be employed in a merger transaction with a larger deal size. Besides, the bulge bracket investment banks are more inclined towards advising public takeovers than the acquisition of private targets. Cash-financed mergers and Stock-financed mergers comprised of $9 \%$ and $36 \%$ of the total M\&As in my sample, respectively. $81 \%$ of the acquisitions are public targets.

${ }^{1}$ Sibilkov and McConnell (2014) provide support for the stationary feature of the top-tier investment banks' position within the M\&A league table across the two decades.

2 The difference between our top-tier investment bank ranking and the one indicated by Golubov et al. (2012) is that UBS and Deutsche Bank replace Barclays and Lazard in the top-tier category. However, in the robustness check, we also include Barclays and Lazard as the top-tier investment bank.

3 See, for example, Gemici and Lai (2019), Lessambo (2019) and Liaw (2013). 
Table 1. Investment bank league table by total transaction value (all sectors)

\begin{tabular}{|c|c|c|c|}
\hline Rank & Financial advisors & Value $(\$ \mathrm{~m})$ & Number of deals \\
\hline 1 & Goldman Sachs \& Co & $19,572,538.3$ & 9,844 \\
\hline 2 & Morgan Stanley & $16,351,577.9$ & 8,887 \\
\hline 3 & JP Morgan & $15,048,616.9$ & 10,438 \\
\hline 4 & Bofa Securities Inc & $13,602,078.2$ & 8,723 \\
\hline 5 & Citi & $12,087,003.5$ & 8,676 \\
\hline 6 & Credit Suisse & $9,772,108.2$ & 8,933 \\
\hline 7 & UBS & $7,594,945.2$ & 7,310 \\
\hline 8 & Deutsche Bank & $7,191,929.9$ & 6,602 \\
\hline 9 & Barclays & $7,149,264.2$ & 4,382 \\
\hline 10 & Lazard & $6,896,118.2$ & 6,366 \\
\hline 11 & Rothschild \& Co & $4,926,516.7$ & 7,099 \\
\hline 12 & Evercore Partners & $3,338,605.3$ & 1,852 \\
\hline 13 & BNP Paribas SA & $2,729,329.5$ & 3,361 \\
\hline 14 & Nomura & $2,685,471.6$ & 4,050 \\
\hline 15 & Centerview Partners LLC & $2,098,141.7$ & 430 \\
\hline 16 & RBC Capital Markets & $1,961,881.1$ & 3,279 \\
\hline 17 & HSBC Holdings PLC & $1,875,281.9$ & 2,266 \\
\hline 18 & Commerzbank AG & $1,545,087.6$ & 1,808 \\
\hline 19 & Houlihan Lokey & $1,385,941.9$ & 5,095 \\
\hline 20 & NatWest Markets & $1,325,470.0$ & 2,556 \\
\hline 21 & PJT Partners Inc & $1,321,772.7$ & 814 \\
\hline 22 & Macquarie Group & $1,299,841.3$ & 2,643 \\
\hline 23 & Jefferies LLC & $1,257,619.5$ & 3,599 \\
\hline 24 & Greenhill \& Co, LLC & $1,245,925.2$ & 902 \\
\hline 25 & Societe Generale & $1,241,931.5$ & 1,825 \\
\hline
\end{tabular}

Note: This table presents the financial advisor league table for M\&As which is extracted from the Thomson Reuters Eikon M\&A database. The number of deals and total deal volumes consisted of announced mergers from 1993 to 2019. All investment banks are given credit for the acquisition if multiple advisors are being employed by the acquirer/target firm. This table does not differentiate between the advisory services provided to either the acquirer or the target firm. The top- 8 firms with the highest total deal value are classified as the top-tier financial advisors while the rests fall into the non-top-tier category. The rank value is the announced transaction value of an M\&A deal and is reported in \$ million.

Table 2. Descriptive statistics

\begin{tabular}{|c|c|c|c|c|c|c|c|c|c|}
\hline \multicolumn{10}{|c|}{ Panel A: Acquirer characteristics } \\
\hline & \multicolumn{3}{|c|}{ All sample } & \multicolumn{3}{|c|}{ Top-tier } & \multicolumn{3}{|c|}{ Non-top-tier } \\
\hline & Mean & Median & $\mathrm{N}$ & Mean & Median & $\mathrm{N}$ & Mean & Median & $\mathrm{N}$ \\
\hline Market cap (\$bn) & 4.15 & 1.90 & 100 & 4.42 & 2.01 & 70 & 3.53 & 1.21 & 30 \\
\hline Book-to-market & 656.15 & 644.16 & 100 & 621.74 & 617.26 & 70 & 736.44 & 696.24 & 30 \\
\hline Leverage & 0.47 & 0.48 & 100 & 0.47 & 0.47 & 70 & 0.46 & 0.49 & 30 \\
\hline Cashflow-to-equity & 74.70 & 73.84 & 100 & 73.14 & 71.59 & 70 & 78.36 & 74.84 & 30 \\
\hline Past stock return & 0.15 & 0.12 & 100 & 0.16 & 0.12 & 70 & 0.14 & 0.12 & 30 \\
\hline Sigma & 0.01 & 0.01 & 100 & 0.01 & 0.01 & 70 & 0.01 & 0.01 & 30 \\
\hline \multicolumn{10}{|c|}{ Panel B: Deal characteristics } \\
\hline & \multicolumn{3}{|c|}{ All sample } & \multicolumn{3}{|c|}{ Top-tier } & \multicolumn{3}{|c|}{ Non-top-tier } \\
\hline & Mean & Median & $\mathrm{N}$ & Mean & Median & $\mathrm{N}$ & Mean & Median & $\mathrm{N}$ \\
\hline Deal value (\$bn) & 1.83 & 1.12 & 100 & 2.07 & 1.52 & 70 & 1.29 & 4.78 & 30 \\
\hline Relative deal size & 871.53 & 560.51 & 100 & 931.16 & 560.51 & 70 & 732.38 & 579.16 & 30 \\
\hline Public deals & 0.81 & - & 100 & 0.83 & - & 70 & 0.77 & - & 30 \\
\hline Private deals & 0.19 & - & 100 & 0.17 & - & 70 & 0.23 & - & 30 \\
\hline All-cash deals & 0.09 & - & 100 & 0.07 & - & 70 & 0.13 & - & 30 \\
\hline All-stock deals & 0.36 & - & 100 & 0.40 & - & 70 & 0.27 & - & 30 \\
\hline Mixed-financing deals & 0.55 & - & 100 & 0.53 & - & 70 & 0.60 & - & 30 \\
\hline
\end{tabular}

Note: The table presents descriptive statistics for acquirer- and deal-specific characteristics. The variable definitions are available in the Appendix. Apart from reporting the full sample, this table also reports the partitioned sample involving deals advised by top-tier and non-top-tier financial advisors separately. The market capitalisation of the acquirer firm and the deal value is reported in \$ billon dollars. 


\section{Methodology}

Short-term event study method, as introduced by Brown and Warner (1985), is employed to examine the abnormal return of the REIT bidders. The expected returns are calculated using the market model ${ }^{4}$. Abnormal returns are calculated by taking the difference between actual returns and expected returns as follows:

$$
A R_{i t}=R_{i t}-\left(\hat{\alpha}_{i}+\hat{\beta}_{i} R_{m t}\right)_{i t},
$$

where: $A R_{i t}$ is the abnormal return for stock $i$ in day $t ; R_{i t}$ is the actual return of stock $i$ in day $t ;\left(\hat{\alpha}_{i}+\hat{\beta}_{i} R_{m t}\right)$ it the expected return of stock $i$ in day $t ; R_{m t}$ is the return of the market portfolio in day $t$. The S\&P 500 index is utilised as a proxy for the market portfolio. $\hat{\alpha}_{i}$ and $\hat{\beta}_{i}$ are estimated based on the estimation period ranges over a $(-240,-41)$ interval, spanning a total of 200 trading days.

The cumulative abnormal return (CAR) will be subsequently calculated by summing up abnormal returns over the event window period (Kothari \& Warner, 2007; Sha et al., 2020):

$$
C A R_{i T}=\sum_{t=1}^{T} A R_{i t}
$$

where: $C A R_{i T}$ is the CAR for stock $i$ for $T$ days of event window. We choose a three days event window, 1 day before announcement date to 1 day after announcement date which is represented by $(-1,+1)$. In the robustness section, the CAR in alternative event windows of five-day, $(-2,+2)$ and eleven-day, $(-5,+5)$ have also been computed.

Cross-sectional regression is employed by testing the relationship between advisor reputation and bidder CARs as follows:

$$
C A R_{i}=\delta_{0}+\delta_{1} \text { top }- \text { tier }_{i}+\delta_{2} X_{i}+\varepsilon_{i}
$$

where: top-tier is a dummy variable which takes a value of 1 if the financial advisor of the bidder is classified as "top-tier", otherwise $0 ; X_{i}$ is a vector of control variables including bidder characteristics and deal characteristics. Following the literature, we include payment method dummy variables, public status of the target dummy variable, relative size of the deal to the acquirer's market capitalisation, market capitalisation, book-to-market ratio, leverage ratio, cash flows to equity measure of the acquirer, past stock return of the acquirer, idiosyncratic volatility of the acquirer and year fixed effects.

\section{Empirical findings}

\subsection{Financial advisor reputation and bidder CARs}

The CAR of the REIT acquirers is illustrated in Table 3. Apart from reporting the CAR of the full sample, this

\footnotetext{
4 Campbell et al. (1998), and Kothari and Warner (2007) contend that other model specifications such as CAPM and FamaFrench asset pricing models do not generate significant enhancement over the market model in terms of the explanatory power and variance of the estimates.
}

Table 3. The abnormal return of acquirer REITs

\begin{tabular}{|l|c|c|c|c|}
\hline & $\begin{array}{c}\text { All } \\
\text { sample }\end{array}$ & Top-tier & Non-top-tier & $\begin{array}{c}\text { (Top-tier) - } \\
\text { (Non-top-tier) }\end{array}$ \\
\hline $\begin{array}{l}\text { Event } \\
\text { window }\end{array}$ & CAR & CAR & CAR & CAR \\
\hline$(-1,+1)$ & $-3.53 \%^{* * *}$ & $-4.41 \%^{* * *}$ & $-1.49 \%$ & $-2.92 \%^{*}$ \\
\hline
\end{tabular}

Note: The table presents the CAR of the REIT acquirers, encompassing both public and private targets in merger deals during the period 1993 to 2019. The market model is employed while the estimation period ranges over a $(-240,-41)$ interval before the merger announcement. The S\&P 500 Composite Index is utilised as a proxy for market movements. The asterisks, ${ }^{* *},{ }^{* *}$ and ${ }^{\star}$ represent the statistical significance at $1 \%, 5 \%$ and $10 \%$ respectively.

table also reports those of the partitioned sample involving deals advised by top-tier and non-top-tier financial advisors. The REIT acquirers experience negative and statistically significant CAR of $-3.53 \%$, which is consistent with the academic literature that M\&As, on average, do not create value for the bidders. The value-destroying nature of M\&As in the REIT sector discovered in this study is also consistent with the significantly negative abnormal gain of the bidding firms documented by Campbell et al. $(1998,2007)$ and Sahin (2005). It is worth noting that the average CAR of the acquirers advised by top-tier financial advisors is significantly lower than the average CAR of the acquirers advised by non-top tier financial advisors.

The cumulative abnormal returns could be easily influenced by the firm and deal-specific characteristics. For instance, while the top-tier investment banks are more likely to advise the acquirers with lower book-to-market ratio, Dong et al. (2006) find that the book-to-market ratio of a bidder is positively related to its abnormal return surrounding merger announcement while Rau (2000) discovers that larger acquirers tend to employ the service of prestigious financial advisors. Thus, multivariate regression analysis has been conducted to distinguish the effect of top-tier advisor on bidder CARs under a ceteris-paribus condition. To ensure there is no multi-collinearity problem, correlations among variable are checked ${ }^{5}$.

Table 4 reports the regression results of Equation (3). Column (1) shows the results of the benchmark regression. The coefficient of top-tier is negative and statistically significant. The empirical findings indicate that the strategic decision to employ a top-tier financial advisor in an M\&A transaction is associated with a negative impact on the shareholder wealth of REIT acquirers. Kale et al. (2003) suggest that it is important to control for the quality of the advisor of the target. In column (2), we also control for the reputation of the financial advisor employed by the target, target top-tier is a dummy variable which takes a value of 1 if the financial advisor of the target is classified as "top-tier", otherwise 0 . The coefficient of target top-tier is insignificant while the coefficient of top-tier remains significant and negative.

\footnotetext{
${ }^{5}$ For brevity, the correlation matrix table is not reported.
} 
In line with the conventional M\&As, the coefficient of private is positive and statistically significant. This positive excess performance experienced by the bidder when acquiring a target firm with private status could be attributed to the liquidity discount proposition as documented by Fuller et al. (2002) and Moeller et al. (2004). Golubov et al. (2012) discover that while the value enhancement effect of toptier investment banks is statistically indistinguishable from zero in their full sample, it is nevertheless positive and statistically significant in public acquisitions. They attributed this positive effect to the extraordinary effort presented by

Table 4. Cross-sectional regression analysis of bidder CARs

\begin{tabular}{|c|c|c|c|}
\hline & (1) & (2) & (3) \\
\hline & CAR & CAR & CAR \\
\hline \multirow[t]{2}{*}{ Top-tier } & $-0.030^{\star *}$ & $-0.030^{*}$ & $-0.036^{\star *}$ \\
\hline & $(-2.02)$ & $(-1.99)$ & $(-2.00)$ \\
\hline \multirow[t]{2}{*}{ Target top-tier } & & 0.020 & 0.022 \\
\hline & & $(1.18)$ & $(1.27)$ \\
\hline \multirow[t]{2}{*}{ Private } & $0.060^{\star * \star}$ & $0.065^{\star * *}$ & 0.048 \\
\hline & $(2.96)$ & (3.19) & $(1.42)$ \\
\hline \multirow[t]{2}{*}{ Top-tier $\times$ private } & & & 0.029 \\
\hline & & & $(0.70)$ \\
\hline \multirow[t]{2}{*}{ All-cash } & -0.015 & -0.012 & -0.012 \\
\hline & $(-0.68)$ & $(-0.52)$ & $(-0.52)$ \\
\hline \multirow[t]{2}{*}{ All-stock } & -0.003 & -0.001 & -0.002 \\
\hline & $(-0.15)$ & $(-0.07)$ & $(-0.12)$ \\
\hline \multirow[t]{2}{*}{ Market cap } & 0.001 & 0.001 & 0.001 \\
\hline & $(0.92)$ & $(0.91)$ & $(0.94)$ \\
\hline \multirow[t]{2}{*}{ Book-to-market } & 0.000 & 0.000 & 0.000 \\
\hline & $(0.98)$ & $(1.27)$ & $(1.24)$ \\
\hline \multirow[t]{2}{*}{ Relative size } & -0.000 & -0.000 & -0.000 \\
\hline & $(-0.92)$ & $(-1.18)$ & $(-1.24)$ \\
\hline \multirow[t]{2}{*}{ Leverage } & -0.024 & -0.017 & -0.017 \\
\hline & $(-0.39)$ & $(-0.27)$ & $(-0.28)$ \\
\hline \multirow[t]{2}{*}{ Cashflows-to-equity } & -0.000 & -0.000 & -0.000 \\
\hline & $(-0.99)$ & $(-0.81)$ & $(-0.78)$ \\
\hline \multirow[t]{2}{*}{ Past stock return } & -0.023 & -0.015 & -0.018 \\
\hline & $(-0.44)$ & $(-0.28)$ & $(-0.34)$ \\
\hline \multirow[t]{2}{*}{ Sigma } & $-11.373^{\star \star \star}$ & $-11.065^{\star * \star}$ & $-11.171^{\star * \star}$ \\
\hline & $(-3.16)$ & $(-3.20)$ & $(-3.23)$ \\
\hline \multirow[t]{2}{*}{ Intercept } & $0.122^{*}$ & 0.104 & 0.101 \\
\hline & $(1.89)$ & $(1.58)$ & $(1.47)$ \\
\hline Year fixed effects & Yes & Yes & Yes \\
\hline$N$ & 100 & 100 & 100 \\
\hline$R^{2}$ & 0.573 & 0.581 & 0.585 \\
\hline
\end{tabular}

Note: The following table presents the regression analysis of the acquirer REITs' CAR on advisor reputation and bidder- and deal-specific characteristics. The full sample consists of 100 observations from 1993 to 2019. The dependent variable is the CAR of acquirers in the three-day event window of $(-1,+1)$. The asterisks, ${ }^{* * *},{ }^{* *}$ and ${ }^{*}$ represent the statistical significance at $1 \%, 5 \%$ and $10 \%$ respectively. The $t$-statistics are reported in parentheses. top-tier financial advisors in the attempt to safeguard their reputational capital. They find that this motivation is absent in private takeovers. Hence, we added the interaction term between top-tier and private in columns (3). The coefficient of Top-tier $\times$ private is insignificant, indicating that the effects of financial advisor reputation on bidder CARs do not differ between a public target and a private target.

Regarding other control variables, only the coefficient of sigma (idiosyncratic volatility) is significant. Sigma represents the uncertainty about the value of the firm, a negative coefficient of sigma indicates that the CARs of the acquirers are lower for acquirers that are more difficult to value.

\subsection{Robustness checks}

\subsubsection{Alternative event window and CAR model}

As there might be information leakage prior to the acquisition announcement, we apply CAR of the alternative event windows of 5 -day $(-2,+2)$ as the dependent variable in the cross-sectional multivariate regressions. This approach serves as an attempt to fully capture the effect of the top-tier financial advisors on REIT M\&As in a longer test window surrounding the merger announcement. This practice is recommended by Fuller et al. (2002) and Ismail (2010) who find that in a small minority of mergers, the acquisition announcement is only entirely captured in the event firms' share price on a longer event window. As the market model may have low predictive power of the expected return, we apply Fama-French 3 factor model to calculate the expected returns, and the abnormal returns is calculated by deducting the expected returns from the actual returns. The Fama-French 3 factors are obtained from Kenneth French's online Data Library.

Table 5 reports the regression results and the results are in conformity with our conclusion. As expected, the

Table 5. Cross-sectional regression analysis of bidder CARs with alternative event windows and CAR model

\begin{tabular}{|l|c|c|}
\hline \multirow{2}{*}{ Top-tier } & $\begin{array}{c}\text { (Alternative event } \\
\text { window) }\end{array}$ & $\begin{array}{c}\text { (Alternative CAR } \\
\text { model })\end{array}$ \\
\cline { 2 - 3 } & $\begin{array}{c}\text { CAR }(-2,+2) \\
\text { Market model }\end{array}$ & $\begin{array}{c}\text { CAR }(-1,+1) \\
\text { Fama-French 3 } \\
\text { factor model }\end{array}$ \\
\hline Bidder characteristics & $-0.030^{*}$ & $-0.027^{\star}$ \\
\hline Deal characteristics & Controlled & Controlled \\
\hline Year fixed effects & Yes & Controlled \\
\hline$N$ & 100 & Yes \\
\hline$R^{2}$ & 0.566 & 100 \\
\hline
\end{tabular}

Note: The following table presents the regression analysis of the acquirer REITs' CAR on advisor reputation and bidder- and deal-specific characteristics. The full sample consists of 100 observations from 1993 to 2019. The asterisks, ${ }^{* * *},{ }^{* *}$ and ${ }^{*}$ represent the statistical significance at $1 \%, 5 \%$ and $10 \%$ respectively. The $t$-statistics are reported in parentheses. 
top-tier variable is significantly negative in the multivariate regression using the CAR of the 5-day and CAR using Fama-French 3 factor model. The superiority of top-tier investment banks is not reflected in their ability to deliver higher abnormal gains for their client firms.

\subsubsection{Alternative financial advisor rankings}

The empirical results on the value-destroying nature of leading financial advisors might be sensitive to the classification of top-tier investment banks. Hence, similar to Golubov et al.s (2012) approach, we identify an alternative cut-off point, replacing the use of top-8 firms as top-tier to include the top-10 firms while the remaining advisory firms fall into the non-top tier category. Furthermore, given that the advisory firms specialising in the real estate M\&A sector might not share the same expertise and reputation among corporate acquisitions across other industries, we have also explored whether using M\&A league tables for REIT mergers in lieu of the M\&A league tables for conventional firms yield similar conclusions.

Table 6 reports the regression results and the results are in conformity with our conclusion. The coefficients of toptier 10 and top-tier RE are negative and statistically significant. It is also economically meaningful, echoing the proposition that the merger deals advised by leading investment banks, either in the top-10 classification or the top-8 firms within the real estate M\&A league table are associated with negative announcement-induced performance.

\subsubsection{Controlling for self-selection bias}

The choice of the financial advisor may not be exogenously determined. As shown in Table 2, REIT acquirers

Table 6. Cross-sectional regression analysis of bidder CARs with alternative financial advisor rankings

\begin{tabular}{|l|c|c|}
\hline \multirow{2}{*}{} & $(1)$ & $(2)$ \\
\cline { 2 - 3 } & CAR & CAR \\
\hline \multirow{2}{*}{ Top-tier 10 } & $-0.036^{* *}$ & \\
\cline { 2 - 3 } & $(-2.29)$ & \\
\hline \multirow{2}{*}{ Top-tier RE } & & $-0.036^{* *}$ \\
\hline Bidder characteristics & Controlled & Controlled \\
\hline Deal characteristics & Controlled & Controlled \\
\hline Year fixed effects & Yes & Yes \\
\hline$N$ & 100 & 100 \\
\hline$R^{2}$ & 0.580 & 0.580 \\
\hline
\end{tabular}

Note: The following table presents the regression analysis of the acquirer REITs' CAR on advisor reputation and bidder- and deal-specific characteristics. The full sample consists of 100 observations from 1993 to 2019. The dependent variable is the CAR of acquirers in the three-day event window of $(-1,+1)$. Top-tier 10 is a dummy variable which takes a value of 1 if the investment bank is in the top-10 classification, otherwise 0 Top-tier is a dummy variable which takes a value of 1 if the investment bank is in the top- 8 firms within the real estate M\&A league table. The asterisks, ${ }^{* *},{ }^{* *}$ and ${ }^{*}$ represent the statistical significance at $1 \%, 5 \%$ and $10 \%$ respectively. The $t$-statistics are reported in parentheses. advised by the leading financial advisors are associated with the characteristics of having a greater size and lower book-to-market value, which suggests that the choice of the financial advisor may be endogenously determined. The choice of the financial advisor is the bidder's decision and a self-selection problem could produce biased estimation of the coefficient of top-tier in Equation (3). Heckman (1979) proposes a two-stage estimator to correct for this bias. Assume that a firm's decision of choosing a top-tier financial advisor is determined by

$$
\begin{aligned}
& \text { Top } \text { tier }_{i}=\delta Z_{i}+u_{i} \text {; } \\
& \text { Top } \text { tier }_{i}=1 \text { iff } \delta Z_{i}+u_{i}>0 \text {; } \\
& \text { Top } \text { tier }_{i}=0 \text { iff } \delta Z_{i}+u_{i} \leq 0 \text {, }
\end{aligned}
$$

where: $Z_{i}$ is a vector of characteristics that affect the choice of a top-tier financial advisor; $u_{i}$ is the error term of the selection equation. When $u_{i}$ and $\varepsilon_{i}$ are correlated, the estimation of Equation (3) will be biased. To correct for such self-selection problem, following the proof of Golubov et al. (2012), Equation (4) is estimated in the first stage and the following equation is estimated in the second stage:

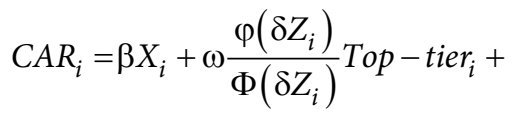

$$
\begin{aligned}
& \omega \frac{-\varphi\left(\delta Z_{i}\right)}{1-\Phi\left(\delta Z_{i}\right)}\left(1-\text { Top }- \text { tier }_{i}\right)+v_{i}= \\
& \beta X_{i}+\omega\left[\frac{\varphi\left(\delta Z_{i}\right)}{\Phi\left(\delta Z_{i}\right)} \text { Top } \text { tier }_{i}+\frac{-\varphi\left(\delta Z_{i}\right)}{1-\Phi\left(\delta Z_{i}\right)}\left(1-{\text { Top } \left.- \text { tier }_{i}\right)}\right)\right]+v_{i}
\end{aligned}
$$

where: $\varphi($.$) and \Phi($.$) are the density function$ and cumulative distribution function of standard normal distribution, respectively. The term

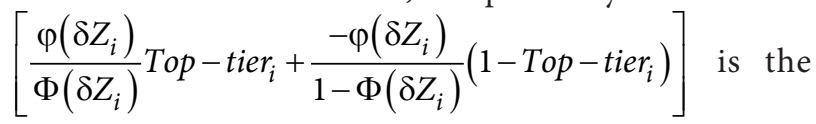
inverse Mills ratio and the coefficient $\omega$ will determine the effect of advisor reputation on CAR. This model also appears in Puri (1996), Gande et al. (1997) Gande et al. (1999) and Fang (2005).

Following Golubov et al. (2012), we should have a variable that appears in the first-stage equation and does not appear in the second-stage equation, a variable that affects the choice of financial advisors but does not affect CARs. Following Golubov et al. (2012) and Fang (2005), we construct a variable scope to serve such identification restriction. The scope variable measures the extent that the top-tier financial advisor has served the bidder in the past. To construct this variable, we download data on equity issues, bond issues, and M\&As from SNL Market Intelligence. The scope variable takes a value of 1 if, in the 5 years prior to the deal, the bidder employed a top-tier financial advisor at least once for an equity issue, a bond issue, or an acquisition. It takes a value of 2 if, in the 5 years prior to the deal, the bidder employed a top-tier financial advisor for two of the three types of transactions. It takes 
a value of 3 if, in the 5 years prior to the deal, the bidder employed a top-tier financial advisor for all three types of transactions. It takes a value of 0 if, in the 5 years prior to the deal, the bidder never employed a top-tier financial advisor for any of those three types of transactions.

Table 7 presents the results of the self-selection model. The coefficient of scope is positive and significant, indicating that scope positively determines the probability of choosing a top-tier financial advisor. This is consistent

Table 7. Heckman two-stage procedure

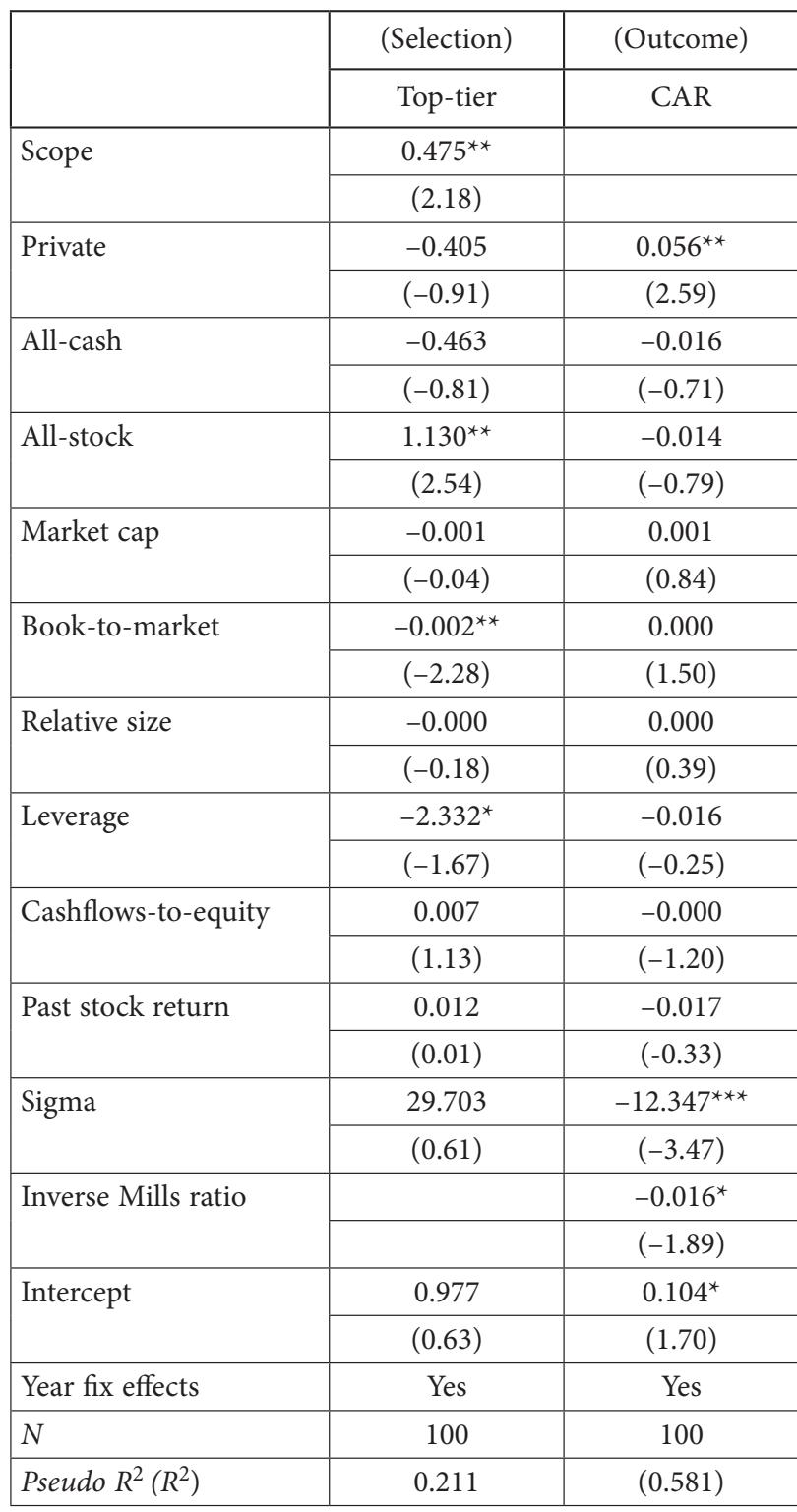

Note: The following table presents the regression result of the self-selection model. The selection equation is the first-stage estimation, where top-tier is the dependent variable. The outcome equation is the second-stage estimation, where CAR with three-day event window is the dependent variable. The full sample consists of 100 observations from 1993 to 2019. The asterisks, ${ }^{* *},{ }^{* *}$ and ${ }^{\star}$ represent the statistical significance at $1 \%, 5 \%$ and $10 \%$ respectively. The $t$-statistics are reported in parentheses. with Golubov et al. (2012) and Fang (2005), bidders that used the services of top-tier bank in the past are more likely to employ a top-tier bank again. The probability of choosing a top-tier investment bank is higher if the payment method is all stock. The probability of choosing a top-tier investment bank is negatively related to book to market ratio and leverage.

From first-stage estimation, inverse Mills ratio is constructed and added as an additional regressor in the second-stage estimation. The coefficient of inverse Mills ratio is negative and significant. This result reflects selfselection, which can be interpreted as follows: Certain observed and unobserved characteristics that increase the likelihood of hiring a top-tier advisor and in turn decrease bidder CAR. After controlling self-selection, our conclusion remains the same, the strategic decision to employ a top-tier financial advisor in an M\&A transaction is associated with a significantly negative wealth implication to the shareholder of REIT acquirers.

\section{Conclusions}

This study explicitly rejects the prima facie proposition that the top-tier investment banks are capable of delivering supernormal value creation to the shareholders of a REIT acquirer in a corporate acquisition. Using the event study method, we find that REIT acquirers advised by market-leading investment banks suffer an average cumulative abnormal return of $-4.41 \%$, whereas REIT acquirers advised by non-top-tier investment banks only suffer an average cumulative abnormal return of $-1.49 \%$. The leading financial advisors are associated with a lower abnormal gain for the bidding firms surrounding the acquisition announcement date. Given the unsatisfactory announcement-induced performance of REIT bidders that retain a top-tier financial advisor, this paper concludes that the practice of employing investment banks based on their prestige or value of transactions done appears to lead to value-destroying M\&As for the REIT acquirers.

Future studies could investigate the possible reasons that REIT acquirer employ top-tier advisors. For instance, whether top-tier advisors are employed to complete the deal. In addition, this study has focussed on the market's reaction to the announcement of a transaction and it may be that the market is not efficiently pricing the impact of the transaction and that a longer term analysis might find that the impact on acquirers advised by top tier firms is more positive. Although for this study we have checked (but not reported given space restrictions) whether some changes in scope (sector differences) lead to different conclusions further research could investigate the detail of the impact on scope to see if this associated with the use of top tier advisers, which might explain the negative impact on returns. 


\section{References}

Allen, P., \& Sirmans, C. (1987). An analysis of gains to acquiring firm's shareholders. Journal of Financial Economics, 18(1), 175-184. https://doi.org/10.1016/0304-405X(87)90067-5

Ambrose, B., Highfield, M., \& Linneman, P. (2005). Real estate and economies of scale: the case of REITs. Real Estate Economics, 33(2), 323-350.

https://doi.org/10.1111/j.1540-6229.2005.00121.x

Andrade, G., Mitchell, M., \& Stafford, E. (2001). New evidence and perspectives on mergers. Journal of Economic Perspectives, 15(2), 103-120. https://doi.org/10.1257/jep.15.2.103

Asquith, P., Bruner, R., \& Mullins, D. (1983). The gains to bidding firms from merger. Journal of Financial Economics, 11(1-4), 121-139. https://doi.org/10.1016/0304-405X(83)90007-7

Bao, J., \& Edmans, A. (2011). Do investment banks matter for M\&A returns? Review of Financial Studies, 24(7), 2286-2315. https://doi.org/10.1093/rfs/hhr014

Bauer, R., Eichholtz, P., \& Kok, N. (2010). Corporate governance and performance: the REIT effect. Real Estate Economics, 38(1), 1-29.

https://doi.org/10.1111/j.1540-6229.2009.00252.x

Bowers, H., \& Miller, R. (1990). Choice of investment banker and shareholders' wealth of firms involved in acquisitions. Financial Management, 19(4), 34-44. https://doi.org/10.2307/3665608

Bradley, M., Desai, A., \& Kim, E. (1988). Synergistic gains from corporate acquisitions and their division between the stockholders of target and acquiring firms. Journal of Financial Economics, 21(1), 3-40. https://doi.org/10.1016/0304-405X(88)90030-X

Brealey, R., Myers, S., \& Allen, F. (2008). Brealey, Myers, and Allen on valuation, capital structure, and agency issues*. Journal of Applied Corporate Finance, 20(4), 49-57. https://doi.org/10.1111/j.1745-6622.2008.00203.x

Brown, S., \& Warner, J. (1985). Using daily stock returns. Journal of Financial Economics, 14(1), 3-31. https://doi.org/10.1016/0304-405X(85)90042-X

Campbell, J., Lo, A., MacKinlay, A., \& Whitelaw, R. (1998). The econometrics of financial markets. Macroeconomic Dynamics, 2(4), 559-562. https://doi.org/10.1017/S1365100598009092

Campbell, R., Ghosh, C., \& Sirmans, C. (2001). The information content of method of payment in mergers: evidence from real estate investment trusts (REITs). Real Estate Economics, 29(3), 361-387. https://doi.org/10.1111/1080-8620.00015

Campbell, R., Ghosh, C., Petrova, M., \& Sirmans, C. (2011). Corporate governance and performance in the market for corporate control: the case of REITs. Journal of Real Estate Finance and Economics, 42(4), 451-480.

https://doi.org/10.1007/s11146-009-9202-2

Campbell, R., Giambona, E., \& Sirmans, C. (2007). The longhorizon performance of REIT mergers. Journal of Real Estate Finance and Economics, 38(2), 105-114. https://doi.org/10.1007/s11146-007-9085-z

Chang, S. (1998). Takeovers of privately held targets, methods of payment, and bidder returns. The Journal of Finance, 53(2), 773-784. https://doi.org/10.1111/0022-1082.315138

Chemmanur, T., \& Fulghieri, P. (1994). Investment bank reputation, information production, and financial intermediation. The Journal of Finance, 49(1), 57-79.

https://doi.org/10.1111/j.1540-6261.1994.tb04420.x da Silva Rosa, R., Lee, P., Skott, M., \& Walter, T. (2004). Competition in the market for takeover advisers. Australian Journal of Management, 29(Suppl. 1), 61-92.

https://doi.org/10.1177/031289620402901S03

Daniels, K., \& Phillips, R. (2007). The valuation impact of financial advisors: an empirical analysis of REIT mergers and acquisitions. Journal of Real Estate Research, 29(1), 57-74. https://doi.org/10.1080/10835547.2007.12091189

Derrien, F., \& Dessaint, O. (2018). The effects of investment bank rankings: evidence from M\&A league tables. Review of Finance, 22(4), 1375-1411. https://doi.org/10.1093/rof/rfx056

Dong, M., Hirshleifer, D., Richardson, S., \& Teoh, S. (2006). Does investor misvaluation drive the takeover market? The Journal of Finance, 61(2), 725-762. https://doi.org/10.1111/j.1540-6261.2006.00853.x

Eckbo, B. E., Giammarino, R. M., \& Heinkel, R. L. (1990). Asymmetric information and the medium of exchange in takeovers: theory and tests. Review of Financial Studies, 3(4), 651-675. https://doi.org/10.1093/rfs/3.4.651

Eichholtz, P., \& Kok, N. (2008). How does the market for corporate control function for property companies? Journal of Real Estate Finance and Economics, 36(2), 141-163. https://doi.org/10.1007/s11146-007-9061-7

Elayan, F., \& Young, P. (1994). The value of control: evidence from full and partial acquisitions in the real estate industry. Journal of Real Estate Finance and Economics, 8(2), 167-182. https://doi.org/10.1007/BF01097036

Fang, L. (2005). Investment bank reputation and the price and quality of underwriting services. The Journal of Finance, 60(6), 2729-2761. https://doi.org/10.1111/j.1540-6261.2005.00815.x

Fuller, K., Netter, J., \& Stegemoller, M. (2002). What do returns to acquiring firms tell us? Evidence from firms that make many acquisitions. The Journal of Finance, 57(4), 1763-1793. https://doi.org/10.1111/1540-6261.00477

Gande, A., Puri, M., \& Saunders, A. (1999). Bank entry, competition, and the market for corporate securities underwriting. Journal of Financial Economics, 54(2), 165-195.

https://doi.org/10.1016/S0304-405X(99)00035-5

Gande, A., Puri, M., Saunders, A., \& Walter, I. (1997). Bank underwriting of debt securities: modern evidence. The Review of Financial Studies, 10(4), 1175-1202. https://doi.org/10.1093/rfs/10.4.1175

Gemici, K., \& Lai, K. (2019). How 'global' are investment banks? An analysis of investment banking networks in Asian equity capital markets. Regional Studies, 54(2), 149-161. https://doi.org/10.1080/00343404.2019.1584393

Glascock, L., Zhang, Y., \& Zhou, T. (2018). A review and extension of merger and acquisition research between REITs and general corporations. Journal of Real Estate Literature, 26(2), 223-253. https://doi.org/10.1080/10835547.2018.12090484

Golubov, A., Petmezas, D., \& Travlos, N. (2012). When it pays to pay your investment banker: new evidence on the role of financial advisors in M\&As. The Journal of Finance, 67(1), 271-311. https://doi.org/10.1111/j.1540-6261.2011.01712.x

Guo, J., Li, Y., Wang, C., \& Xing, X. (2020). The role of investment bankers in M\&As: new evidence on acquirers' financial conditions. Journal of Banking \& Finance, 119, 105298. https://doi.org/10.1016/j.jbankfin.2018.02.004

Heckman, J. J. (1979). Sample selection bias as a specification error. Econometrica, 47(1), 153-161.

https://doi.org/10.2307/1912352 
Hunter, W., \& Jagtiani, J. (2003). An analysis of advisor choice, fees, and effort in mergers and acquisitions. Review of Financial Economics, 12(1), 65-81.

https://doi.org/10.1016/S1058-3300(03)00007-7

Ismail, A. (2010). Are good financial advisors really good? The performance of investment banks in the M\&A market. Review of Quantitative Finance and Accounting, 35(4), 411-429. https://doi.org/10.1007/s11156-009-0155-6

Jensen, M., \& Meckling, W. (1976). Theory of the firm: managerial behavior, agency costs and ownership structure. Journal of Financial Economics, 3(4), 305-360. https://doi.org/10.1016/0304-405X(76)90026-X

Kale, J., Kini, O., \& Ryan, H. (2003). Financial advisors and shareholder wealth gains in corporate takeovers. The Journal of Financial and Quantitative Analysis, 38(3), 475-501. https://doi.org/10.2307/4126728

Kothari, S., \& Warner, J. (2007). The econometrics of event studies. In B. E. Eckbo (Ed.), Handbook of corporate finance: empirical corporate finance (Vol. 1, chapter 1, pp. 3-36). Elsevier/ North-Holland.

Lessambo, F. (2019). The U.S. banking system. Palgrave Macmillan. https://doi.org/10.1007/978-3-030-34792-5

Li, J., Elayan, F., \& Meyer, T. (2001). Acquisitions by real estate investment trusts as a strategy for minimization of investor tax liability. Journal of Economics and Finance, 25(1), 115134. https://doi.org/10.1007/BF02759690

Liaw, K. (2013). The business of investment banking. Wiley. https://doi.org/10.1002/9781119202332

Ling, D., \& Petrova, M. (2011). Why do REITs go private? Differences in target characteristics, acquirer motivations, and wealth effects in public and private acquisitions. Journal of Real Estate Finance and Economics, 43(1-2), 99-129. https://doi.org/10.1007/s11146-010-9295-7

Manne, H. (1965). Mergers and the market for corporate control. Journal of Political Economy, 73(4), 351-351. https://doi.org/10.1086/259036

Mitchell, M., \& Mulherin, J. (1996). The impact of industry shocks on takeover and restructuring activity. Journal of Financial Economics, 41(2), 193-229.

https://doi.org/10.1016/0304-405X(95)00860-H

Moeller, S., Schlingemann, F., \& Stulz, R. (2004). Firm size and the gains from acquisitions. Journal of Financial Economics, 73(2), 201-228. https://doi.org/10.1016/j.jfineco.2003.07.002

Morck, R., Shleifer, A., \& Vishny, R. (1990). Do managerial objectives drive bad acquisitions? The Journal of Finance, 45(1), 31-48. https://doi.org/10.1111/j.1540-6261.1990.tb05079.x

Myers, S., \& Majluf, N. (1984). Corporate financing and investment decisions when firms have information that investors do not have. Journal of Financial Economics, 13(2), 187-221. https://doi.org/10.1016/0304-405X(84)90023-0

Puri, M. (1996). Commercial banks in investment banking conflict of interest or certification role? Journal of Financial Economics, 40(3), 373-401.

https://doi.org/10.1016/0304-405X(95)00855-9
Rau, P. (2000). Investment bank market share, contingent fee payments, and the performance of acquiring firms. Journal of Financial Economics, 56(2), 293-324. https://doi.org/10.1016/S0304-405X(00)00042-8

Rau, P., \& Rodgers, K. (2002). Do bidders hire top-tier investment banks to certify value? SSRN Electronic Journal. https://doi.org/10.2139/ssrn.298172

Rhee, M., \& Valdez, M. (2009). Contextual factors surrounding reputation damage with potential implications for reputation repair. Academy of Management Review, 34(1), 146-168. https://doi.org/10.5465/amr.2009.35713324

Sahin, O. F. (2005). The performance of acquisitions in the real estate investment trust industry. Journal of Real Estate Research, 27(1), 321-342.

https://doi.org/10.1080/10835547.2005.12091161

Servaes, H. (1991). Tobin's Q and the gains from takeovers. The Journal of Finance, 46(1), 409-419. https://doi.org/10.1111/j.1540-6261.1991.tb03758.x

Servaes, H., \& Zenner, M. (1996). The role of investment banks in acquisitions. Review of Financial Studies, 9(3), 787-815. https://doi.org/10.1093/rfs/9.3.787

Seth, A. (1990). Sources of value creation in acquisitions: an empirical investigation. Strategic Management Journal, 11(6), 431-446. https://doi.org/10.1002/smj.4250110603

Sha, Y. Z., Kang, C. L., \& Wang, Z. L. (2020). Economic policy uncertainty and mergers and acquisitions: evidence from China. Economic Modelling, 89, 590-600. https://doi.org/10.1016/j.econmod.2020.03.029

Shleifer, A., \& Vishny, R. (1989). Management entrenchment. Journal of Financial Economics, 25(1), 123-139. https://doi.org/10.1016/0304-405X(89)90099-8

Shleifer, A., \& Vishny, R. (1997). A survey of corporate governance. The Journal of Finance, 52(2), 737-783. https://doi.org/10.1111/j.1540-6261.1997.tb04820.x

Sibilkov, V., \& McConnell, J. (2014). Prior client performance and the choice of investment bank advisors in corporate acquisitions. Review of Financial Studies, 27(8), 2474-2503. https://doi.org/10.1093/rfs/hhu031

Travlos, N. (1987). Corporate takeover bids, methods of payment, and bidding firms' stock returns. The Journal of Finance, 42(4), 943-963. https://doi.org/10.1111/j.1540-6261.1987.tb03921.x

Walter, T., Yawson, A., \& Yeung, C. (2008). The role of investment banks in M\&A transactions: fees and services. PacificBasin Finance Journal, 16(4), 341-369. https://doi.org/10.1016/j.pacfin.2007.08.002

Womack, K. (2010). Real estate mergers: corporate control \& shareholder wealth. Journal of Real Estate Finance and Economics, 44(4), 446-471. https://doi.org/10.1007/s11146-010-9251-6 


\section{Appendix}

\section{Variable description}

\begin{tabular}{|c|c|}
\hline \multicolumn{2}{|r|}{ Panel A: Dependent variables } \\
\hline Variable & Definition \\
\hline CAR & $\begin{array}{l}\text { Cumulative abnormal return of the acquirer firms are calculated using the standard market } \\
\text { model across three different event windows of } 3 \text { days }(-1,+1), 5 \text { days }(-2,+2) \text { and } 11 \text { days } \\
(-5,+5) \text { respectively, with the latter two event windows utilised for robustness purpose. The } \\
\text { estimation period ranges over a }(-240,-41) \text { interval, spanning a total of } 200 \text { trading days }\end{array}$ \\
\hline \multicolumn{2}{|r|}{ Panel B: Bidder characteristics } \\
\hline Market cap & The market capitalisation of equity of the bidder 4 weeks prior to the acquisition announcement \\
\hline Book-to-market & $\begin{array}{l}\text { Book value of equity of the acquirer firm in its last financial year prior to the merger over its } \\
\text { market capitalisation } 4 \text { weeks prior to the acquisition announcement }\end{array}$ \\
\hline Leverage & $\begin{array}{l}\text { Total debt of the acquirer firm over its total book value of assets in the last financial year prior } \\
\text { to the merger }\end{array}$ \\
\hline Cashflows-to-equity & $\begin{array}{l}\text { Fund from operations (FFO) of the acquirer firm over its market capitalisation } 4 \text { weeks prior } \\
\text { the acquisition announcement }\end{array}$ \\
\hline Past stock return & $\begin{array}{l}\text { Buy-and-hold return of the acquirer firm's stock over the period beginning } 205 \text { days and ending } \\
6 \text { days prior to the acquisition announcement }\end{array}$ \\
\hline Sigma & $\begin{array}{l}\text { Standard deviation of the acquirer firm's market-adjusted (adjusted by Fama-French } 3 \text { factor } \\
\text { model) daily return over the period beginning } 205 \text { days and ending } 6 \text { days prior to the } \\
\text { acquisition announcement }\end{array}$ \\
\hline \multicolumn{2}{|r|}{ Panel C: Deal characteristics } \\
\hline Top-tier & $\begin{array}{l}\text { Dummy variable equals to one if an event firm is advised by either one or multiple financial } \\
\text { advisors ranked among top- } 8 \text { in the M\&A league table and zero otherwise }\end{array}$ \\
\hline All-cash & Dummy variable equals to one if the deal consideration is solely cash-financed \\
\hline All-stock & Dummy variable equals to one if the deal consideration is solely stock-financed \\
\hline Private & $\begin{array}{l}\text { Dummy variable equals to one if the target is a private firm, as well as not being a publicly } \\
\text { listed entity and zero otherwise }\end{array}$ \\
\hline Deal size & $\begin{array}{l}\text { Transaction value of a merger as reported in the SNL Global Market Intelligence M\&A } \\
\text { transaction database }\end{array}$ \\
\hline Relative deal size & Transaction value of a merger over the acquirer's market capitalisation \\
\hline
\end{tabular}

